\title{
Balance of payments and the relationship to national accounts
}

This section is intended to help users of the Pink Book gain a better understanding of how the data fit within the broader economic accounts framework. It can be read as a standalone, although it makes several references to Blue Book tables and so readers are advised to have access to these if possible.

\section{Introduction}

Conceptually, the balance of payments, including the international investment position, form part of the broader system of the UK National Accounts. The National Accounts provide a comprehensive and systematic set of statistics for the UK economy, with information on economic transactions, other changes in the levels of assets and liabilities, and the levels of assets and liabilities themselves. The UK National Accounts have generally been compiled according to the European System of Accounts (ESA95). Linkages between the UK balance of payments and National Accounts are reinforced by the fact that the UK balance of payments are compiled at the same time as the National Accounts, as a component of the sector accounts and using many common data sources.

The National Accounts are a closed system in which both ends of every transaction involving a resident economic entity are recorded. A set of accounts is introduced to capture transactions that involve economic relationships with non-resident entities. These accounts are known as the 'rest of the world accounts' and are presented from the perspective of non-residents rather than residents. Consequently, entries in the balance of payments (which show transactions from the perspective of residents) are reversed in the presentation of the rest of the world accounts. The accounts for resident entities, which consist of the production, income and accumulation accounts, are described in more detail below.

Two important accounting differences occur when comparing the balance of payments and the National Accounts. First, each transaction is recorded twice in the balance of payments (double entry) and four times in the National Accounts (quadruple entry). This is because in the balance of payments the activity of only one transactor is recorded, that of the resident entity (with a non-resident entity), whereas in the National Accounts the activity of both transactors is recorded (that is, the activity of either two residents or a resident and a non-resident). Second, in the balance of payments, transactions are shown from the perspective of the resident entity; whereas in the National Accounts, transactions are shown from the perspective of the resident in the production, income and accumulation accounts, and from the perspective of the non-resident in the rest of the world account.

\section{Relationship between National Accounts and balance of payments concepts and classifications}

Because the balance of payments, including the international investment position, forms an integral part of the National Accounts, there is complete concordance between them in concept and classification, although the extent of cross-classifications may differ between the two systems.

The balance of payments and National Accounts identify resident producers and consumers identically, and both invoke the same concepts of economic territory and centre of economic interest. Both use market prices as the primary concept of valuation of transactions and they adopt identical concepts of accrual accounting. The systems use identical conversion procedures to convert transactions which take place in foreign currency to UK currency.

While for some purposes it would be convenient if classifications used in the rest of the world accounts and the balance of payments accounts were identical, differences between the two are justifiable because on occasion they serve different purposes. For example, in the balance of payments financial account, precedence is given to classification of transactions by type of investment (that is, direct, portfolio, other, financial derivatives and reserve assets), whereas in the rest of the world financial account the instrument of investment is the primary classification. More important is the fact that concepts, definitions and classifications are consistent between the two systems.

The production, income and capital accounts of the National Accounts

The National Accounts tables reflect the basic aspects of economic life (production, income, consumption, accumulation and wealth). For many analysts, Gross Domestic Product (GDP) is the key economic aggregate as it measures the total value added for the UK economy in any period. GDP may be measured as:

- the total value of output less the cost of goods and services used in the production process (intermediate consumption). This is referred to as the output (or production) approach

- the value of income accruing from the production process to each of the 
factors of production (plus net taxes on production and imports). This is referred to as the income approach

- total final expenditure on goods and services during the period, referred to as the expenditure approach

Conceptually these measures are equal, but because different and imperfect data sources are used to measure each approach, the measures may differ in practice. This difference is reflected in the statistical discrepancy item. The National Accounts are regularly benchmarked to balanced annual supply and use (input-output) tables. This ensures that, except for the latest year, the three measures of GDP are equal on an annual basis, though there will still be a statistical discrepancy between the quarterly estimates based on the three approaches.

Blue Book Table 1.2 presents the Gross Domestic Product Account for the whole economy, the derivation of GDP using the expenditure approach and the income approach. Table 1.7.1, the Production Account, shows the derivation of GDP using the production approach.

- The expenditure-based measure of GDP is derived as final consumption expenditure by government and households, plus investment in fixed capital formation and changes in inventories, plus exports minus imports of goods and services, plus (or minus) the statistical discrepancy. Exports and imports are the same as the balance of payments components, exports and imports of goods and services

- The income-based measure of GDP shows the components of factor income, namely compensation of employees, gross operating surplus and mixed incomes, plus taxes less subsidies on production and imports

- The production-based measure of GDP is shown as total gross output at purchasers' prices less intermediate consumption
For the purpose of discussion here, all values are in current prices.

Blue Book Tables 1.7.3, 1.7.4 and 1.7.6 present the National Income, Secondary Distribution of Income and Use of Income Accounts, showing the derivation of gross national income, gross disposable income and use of gross disposable income. Gross national income is equivalent to GDP plus property income receivable from non-residents, less property income payable to non-residents.

These primary income items are the same as the balance of payments income components which are used in the derivation of gross saving (gross disposable income less consumption) and net saving (gross saving less consumption of fixed capital). Tables 1.7.3 and 1.7.4 illustrate how the various balance of payments income and current transfers components affect the nation's saving. To derive gross disposable income, net secondary income receivable from non-residents is added to gross national income; secondary income items are equivalent to the net current transfer components in the balance of payments.

Table 1.7.6 deals with use of gross disposable income and shows the derivation of gross saving (gross disposable income less consumption) and net saving (gross saving less consumption of fixed capital).

Blue Book Table 1.7.7, the National Capital Account, shows the link between gross saving and net lending/borrowing (to/from the rest of the world). The latter is derived as gross saving plus net capital transfers from non-residents less investment in fixed capital and inventories and the net acquisitions of non-produced, non-financial assets from non-residents. The items net capital transactions and net acquisitions of non-produced non-financial assets are both sourced from the balance of payments capital account. The capital account was introduced into the balance of payments to emphasise this clear relationship between the balance of payments and the National Accounts.

\section{The financial account and balance sheet of the National Accounts}

Net lending/borrowing is also the balance shown in Blue Book Table 1.7.8, the Financial Account. The financial account shows how the net lending/ borrowing is financed through a combination of transactions in financial assets and liabilities. Table 1.7.8 is the UK's Financial Account and includes transactions for all sectors. Financial transactions between all resident sectors can be offset and eliminated. This results in the UK's Financial Account for the total economy being equal to the inverse of the financial account for the rest of the world sector and equivalent to the balance of payments financial account.

However, there are some important differences in classification emphasis between Table 1.7.8 and the balance of payments financial account. In Table 1.7.8 the emphasis is on instrument of investment (such as currency and deposits, securities, loans, and equity), while in the balance of payments financial account, the emphasis is on type of investment (direct investment, portfolio investment, financial derivatives, other investment and reserve assets). Both presentations give emphasis to the asset and liability classification.

Blue Book Table 1.7.9, the UK's Financial Balance Sheet, shows the UK's financial assets, and liabilities and net worth at the end of the period. Financial assets and liabilities measure financial claims and liabilities between all sectors of the economy. Claims and liabilities between resident sectors can be offset and eliminated. This results in the UK's Financial Balance Sheet being the equivalent of the international investment position statement for the UK.

Again, there are some important classification differences between Table 1.7.9 and the international investment position statement. In Table 1.7.9 the 
emphasis is on instrument of investment, while in the international investment position statement the emphasis is on type of investment. Both presentations give emphasis to the asset and liability classification.

\section{Rest of the world accounts of the National Accounts}

There are five accounts for the rest of the world in the National Accounts shown in the Blue Book. These are:

- Table 7.1.0, the External account of goods and services

- Table 7.1.2, the External account of primary incomes and current transfers
- Table 7.1.7, the External capital account

- Table 7.1.8, the External Financial Account

- Table 7.1.9, the External Balance Sheet Accounts

The external accounts are published quarterly in UK Economic Accounts. As mentioned earlier, these accounts are required to close the system of National Accounts and, while essentially the same as the balance of payments accounts and international investment position statement, they are compiled from the perspective of the non-resident transactor. Table 7.1.2 is essentially the current account of the balance of payments, Table 7.1.7 the capital account, Table 7.1.8 the financial account, and Table 7.1.9 the international investment position. The reader should be able to readily identify the counterpart entries in all of these tables.

\section{Transactions with the EU}

Blue Book Table 12.1 shows UK official transactions with institutions of the EU from a UK National Accounts perspective. It has been recreated in the Pink Book as Table 9.9 using balance of payments terminology. 